"I swear to be courageous, to maintain my opinion fearlessly against any hostile belief that refuses to tolerate it.

"And I swear to renounce it the moment I see or am shown a convincing reason for doing so."

\title{
A. WOHLGEMUTh.
}

(') Quoted from P. L. Couchond: The Enigma of Jesus. With an Introduction by Sir James Fraser. London: Watts \& Co., r924.

\section{A ROYAL COMMISSION ON LUNACY LAW.}

THE King has been pleased to approve the appointment of a Royal Commission with the following terms of reference :

(I) To inquire as regards England and Wales into the existing law and administrative machinery in connection with the certification, detention and care of persons who are or are alleged to be of unsound mind;

(2) To consider as regards England and Wales the extent to which provision is or should be made for the treatment without certification of persons suffering from mental disorder ;

And to make recommendations.

The Commission will be composed as follows :

The Right Hon. H. P. Macmillan, K.C. (chairman), the Earl Russell, Lord Eustace Percy, M.P., Sir Thomas Hutchison, Bt., Sir Humphry Rolleston, K.C.B., M.D., D.C.L., LL.D., Sir Ernest Hiley, K.B.E., Sir David Drummond, C.B.E., M.D., D.C.L., Mr. W. A. Jowitt, K.C., M.P., Mr. F. D. MacKinnon, K.C., Mr. H. Snell, M.P., Mrs. C. J. Matthew, Miss Madeline Symons, with Mr. P. Barter, of the Ministry of Health, as Secretary.

All communications regarding the Commission should be addressed to "The Secretary, Royal Commission on Lunacy and Mental Disorder, Ministry of Health, Whitehall, S.W. r."

Applications to give evidence before the Commission should be made in writing; personal interviews cannot be granted in this connection.

\section{OBITUARY.}

Richard Henry HeUrteey Sankey, M.R.C.S., L.S.A.

The doyen of our Association died on May 13, 192I, at the age of 90. He was appointed Assistant Medical Officer to Dr. Leigh at Littlemore Asylum (Oxford and Berks County Asylum) in 1854. After serving as Assistant Medical Officer for seven years he was appointed Medical Superintendent. This post he beld until he retired in 1906, after 52 years' service. He retained his faculties until the end of his life. His sight, hearing and memory were very good. He was always bright and cheerful and never depressed. He married in 1869 and had one son and two daughters. His wife died in March, 1914.

Albert Irwin EAdes, L.R.C.P.\&S.Irel., Medical Superintendent, North Riding Mental Hospital.

THE tragic death of Dr. Albert Irwin Eades on Easter Monday caused widespread distress amongst all who knew him.

Eades was a man who required knowing.

A first impression was apt to be that of a cold, austere person, entirely selfsufficient, whereas this was very far removed from the true nature of the man. He was warm-hearted, generous to a degree, and possessed a store of dry humour which made him a most entertaining companion.

He was essentially a man's man, and enjoyed nothing better than a quiet evening round the fire with a friend and a pipe, and if that friend were in his specialty, so much the better, for he was entirely bound up in his work, and never wearied of discussing ways and means of improving the lot of his patients.

He was a shrewd judge of character, and his reminiscences of the various colleagues he had served with in the course of his career at Nottingham, Prestwich 
and Winwick were always intensely interesting and often very amusing. He was a man of unbounded energy. Up at 7 a.m., he saw all his heads of departments before he breakfasted, and much that he might with advantage to himself have delegated to others he carried out himself.

He was loved by his patients and had a most intimate knowledge of everyone under his care-one had only to walk round the wards with him to perceive both these facts.

Albert Irwin Eades was born on June 21, 1873, in the town of Sligo. His father was W. C. Eades, M.A., a distinguished classical scholar who entered the Indian Civil Service, but was invalided in 1866 , although he lived till 1919 .

Dr. Eades was educated at the Diocesan Schools of Sligo and Elphin, co. Roscommon, both of which were then presided over by his father. Eades showed the same aptitude for the classics as his father, and won many prizes.

In 1892 he entered the Royal College of Surgeons, Dublin, and obtained the Licence in 1897, after a distinguished career, being awarded the Mayne Scholarship, which is the blue riband of the College.

Most of his professional life has been spent in mental work, and he served in various asylums until, in the year 1905, he succeeded Dr. Hingston as Superintendent of the North Riding Mental Hospital

He had not been in robust health for some time: the strain of the war years told severely on one of his temperament. Last autumn he was much debilitated by a succession of large boils, and there can be little doubt that the Harnett case in his run-down state preyed on his mind to a morbid degree.

The love and esteem in which he was held was given eloquent testimony to by the large attendance at the moving funeral service in the Hospital Chapel on the day of his burial.

Committee, staff, patients, and the local members of the medical profession were present in large numbers. Of our own specialty there were present Prof. Shaw Bolton, Dr. Brunton of Nottingham, his former Senior Assistant, Dr. Rutherford Jeffrey, Dr. Mackenzie, Dr. Simpson, Dr. Yellowlees, and had it not unfortunately been the occasion of the Divisional Meeting of the M.P.A. at Prestwich, many others would doubtless have paid their last tribute.

Eades had no very near relations to mourn his loss and he was a bachelor, but he will be greatly missed in the sphere in which he laboured so successfully, as is shown by the resolution which his committee have placed on record and which I repeat in full :

" The Visiting Committee of the North Riding of Yorkshire Mental Hospital desire to express their profound grief and regret for the death of Dr. Albert Irwin Eades, their Medical Superintendent, and to record their high appreciation of his work for nineteen years past, during which, by his unrivalled medical skill, conspicuous administrative ability, and, above all, his intensely conscientious devotion to duty, he raised the Hospital to the highest standard of efficiency, both in the care and treatment of patients and in the administration of its finances. They further wish to offer to his relatives their deepest sympathy in their loss and sorrow."

E. S. Simpson.

\section{CORRESPONDENCE.}

To the Editors of the Journal of Mental Science.

I have only just received from Messrs. Longmans the review of my Applied Philosophy, and I should like to write a line to the writer. Being signed gives it a personal touch and adds interest to it, as obviously we are both discussing a subject which appeals to us both. If we met in person I think we should agree-if only to differ.

With much that he says I am not going to quarrel. The fact is, it should have been written at the beginning instead of the end of life-only I don't think I thus saw things at the beginning of life. The thought wants working out and it wants years to do it. But evidently I have not made clear what my central thought is. It is not to demonstrate the truism, as stated, but to urge that this truism should 